\title{
Sistem Deteksi Penggunaan Masker saat Keluar Rumah Berbasis Smartphone dan Arduino
}

\author{
Emil Naf'an, S.Kom.,M.Kom ${ }^{1 \square}$, Sepsa Nur Rahman, S.Kom., M.Kom², Sylvia Kurniati ${ }^{3}$ \\ 1,2,3 Jurusan Sistem Komputer, Fakultas Ilmu Komputer, Universitas Putra Indonesia "YPTK” Padang
}

emilnafan@upiyptk.ac.id

\begin{abstract}
This study aims to create a system that is able to detect the use of masks by residents of the house when leaving the house. The designed system is placed near the outer door of the house. The system is controlled by Smartphone and Arduino Mega2560. This is one of the efforts to help the government to reduce the spread of the Covid-19 virus. The system works based on information from the camera (webcam) which functions to detect faces when leaving the house. In this research, the components used are Wifi ESP8266 module, external webcam, LCD (Liquid Crystal Display) 16X2, Red indicator LED, Blue indicator LED, Green indicator LED, Android Smartphone and buzzer. When the webcam detects someone using a mask, the Green indicator LED lights up, then the words "Can leave the house" appear on the LCD and a notification appears to telegram. When the webcam detects someone is not wearing a mask, the Red indicator LED is on, then the words "Not allowed to leave the house" appear on the LCD, the buzzer will sound and a notification will appear to telegram. From the results of testing the face classification in using a mask and not using a mask, an accuracy of 98.5 percent is obtained. Likewise, from the overall system testing, the results obtained that testing all user conditions carried out (1. No people in front of the camera, 2. Residents of the house wearing masks, 3.Residents of the house not wearing masks) can be detected properly and produce appropriate messages. on the LCD. This proves that the detection system for using masks when leaving the house can work well. Thus the system designed can be used and placed in every home, so it is hoped that it can reduce the number of Covid-19 virus spreads.
\end{abstract}

Keywords: External Webcam, Arduino Mega2560, Smartphone, Indicator LED, Buzzer, Liquid Crystal Display (LCD)

\begin{abstract}
Abstrak
Penelitian ini bertujuan untuk membuat suatu sistem yang mampu mendeteksi penggunaan masker oleh penghuni rumah saat keluar dari rumah. Peralatan yang dirancang diletakkan di dekat pintu luar bagian dalam rumah. Sistem dikendalikan oleh Smartphone dan Arduino Mega2560. Hal ini merupakan salah satu upaya dalam membantu pemerintah untuk menurunkan angka penyebaran virus Covid-19. Sistem bekerja berdasarkan informasi dari kamera (webcam) yang berfungsi mendeteksi wajah saat keluar rumah. Dalam penelitian ini komponen yang digunakan adalah module Wifi ESP8266, webcam eksternal, LCD (Liquid Crystal Display) 16X2, LED indikator Merah, LED indikator Biru, LED indikator Hijau, Smartphone Android dan buzzer. Pada saat webcam mendeteksi seseorang menggunakan masker LED indikator Hijau menyala, lalu tampil tulisan "Boleh Keluar Rumah" pada LCD dan tampil notifikasi ke aplikasi telegram. Ketika webcam mendeteksi seseorang tidak menggunakan masker LED indikator Merah hidup, lalu tampil tulisan "Tidak Boleh Keluar Rumah" pada LCD, buzzer akan berbunyi dan tampil notifikasi ke aplikasi telegram. Dari hasil pengujian klasifikasi wajah dalam menggunakan masker dan yang tidak menggunakan masker diperoleh akurasi sebesar 98.5 persen. Begitu juga dari pengujian sistem secara keseluruhan diperoleh hasil bahwa pengujian semua kondisi pengguna yang dilakukan (1. Tidak ada orang di depan kamera, 2. Penghuni rumah menggunakan masker, 3.Penghuni rumah tidak menggunakan masker) dapat dideteksi dengan baik serta menghasilkan pesan yang sesuai pada LCD. Ini membuktikan bahwa sistem deteksi penggunaan masker saat keluar rumah dapat bekerja dengan baik. Dengan demikian sistem yang dirancang bisa digunakan dan ditempatkan di setiap rumah, sehingga diharapkan bisa menurunkan angka penyebaran virus Covid-19.
\end{abstract}

Kata kunci: Webcam Eksternal, Arduino Mega2560, Smartphone, LED Indikator, Buzzer, Liquid Crystal Display (LCD)

(c) 2021 Jurnal KomtekInfo

\section{Pendahuluan}

Sejak awal Maret 2020, untuk pertama kalinya pemerintah mengumumkan dua kasus pasien positif Covid-19 di Indonesia. Namun Pakar Epidemiologi Universitas Indonesia (UI), Pandu Riono menyebutkan virus corona jenis SARS-CoV-2 sebagai penyebab Covid-19 itu sudah masuk ke Indonesia sejak awal Januari [1]. Pemerintah Indonesia sudah melakukan langkah-langkah antisipasi antara lain menggunakan Health Alert Card [2] atau Yellow Card dan juga Thermal Scanner [3] untuk mengecek suhu tubuh diatas 38,5 derajat Celsius [4] di pintu masuk dan keluar Negara Republik Indonesia. Disamping itu setiap orang diharuskan untuk menggunakan masker saat bepergian ke luar dari rumah. Hal ini berguna untuk menekan penyebaran virus Covid-19.

Sejalan dengan perkembangan teknologi yang tumbuh dengan sangat pesat, alat yang menggunakan 
teknologi elektronika dan mikrokontroler semakin berkembang pula. Saat ini sudah banyak ditemukan peralatan yang menggunakan teknologi tersebut. Namun belum ditemukan alat berbasis Arduino dan Smartphone yang berfungsi mendeteksi penggunaan masker oleh penghuni rumah saat mereka bepergian (keluar rumah). Padahal penggunaan masker merupakan salah satu upaya untuk menekan penyebaran virus Covid-19.[5]

Penyuluhan tentang pentingnya penggunaan masker sudah pernah dilakukan oleh Seri Asnawati Munthe [6]. Pada penelitian ini dilakukan penyuluhan dan sosialisasi penggunaan masker di Desa Sifahandro Kecamatan Sawo namun belum ditemukan adanya dampak positif karena masih banyak masyarakat yang keluar rumah tidak menggunakan masker dan kebanyakan masyarakat tidak menjaga jarak \pm 2 meter antara satu dengan yang lain. Hal yang sama juga pernah dilakukan oleh Septiawan Ardiputra [7]. Pada program pengabdian masyarakat ini, masyarakat perlu mendapatkan edukasi cara pencegahan penularan Covid-19. [8][5] Namun penelitian tersebut lebih dikhususkan untuk mensosialisasikan dan mempraktekan langsung kepada masyarakat bahwa penggunaan masker memiliki manfaat yang sangat besar untuk pencegahan penularan virus Covid-19. Untuk itu diperlukan suatu alat yang mampu mendeteksi seseorang dalam penggunaan masker pada saat keluar rumah menggunakan Arduino Mega 2560 [9] [10] [11] sebagai pengendali.

Dalam penelitian ini komponen yang digunakan adalah Module Wifi ESP8266 [12], webcam eksternal [13], LCD (Liquid Crystal Display) 16x2 [14], LED indikator Merah [15], LED indikator Biru, LED indikator Hijau, Smartphone android dan buzzer [16]. Untuk mendeteksi wajah yang menggunakan masker atau tidak digunakan aplikasi teachablemachine [17]. Pada saat webcam mendeteksi seseorang menggunakan masker maka LED indikator Hijau menyala. Pada LCD tampil pesan "Boleh Keluar Rumah" dan tampil notifikasi dengan pesan yang sama pada aplikasi telegram. Ketika webcam mendeteksi seseorang tidak menggunakan masker maka LED indikator Merah menyala. Pada LCD tampil pesan "Tidak Boleh Keluar Rumah". Selanjutnya buzzer akan berbunyi dan notifikasi dengan pesan yang sama akan dikirim ke aplikasi telegram. Dengan demikian diharapkan alat tersebut mampu mengatasi masalah penggunaan masker yang wajib digunakan saat keluar rumah sehingga dapat mencegah penularan virus Covid-19.

\section{Metodologi Penelitian}

Penelitian ini bertujuan untuk merancang dan membuat suatu sistem deteksi penggunaan masker saat keluar rumah yang dikendalikan oleh Smartphone dan Arduino Mega2560. Metode yang dilakukan dalam penelitian ini yaitu : Perancangan Sistem,
Implementasi Sistem dan Pengujian Sistem. Selanjutnya hasil pembahasan terhadap pengujian sistem tersebut, diperoleh kesimpulan dari sistem yang dirancang.

\subsection{Perancangan Sistem}

Dalam melakukan perancangan sistem terdapat dua hal yang perlu dilakukan yaitu perancangan dari segi perangkat keras (hardware) maupun perangkat lunak (software). Perancangan tersebut didasari atas ketentuan antara lain :

a. Sistem harus mampu mendeteksi wajah yang menggunakan masker dan tidak menggunakan masker menggunakan kamera.

b. Jika saat keluar rumah, penghuni tersebut menggunakan masker akan tampil pesan "BOLEH KELUAR RUMAH" pada LCD. Disamping itu pesan ini juga dikirim ke Smartphone penghuni rumah melalui aplikasi telegram.

c. Jika saat keluar rumah, penghuni tersebut tidak menggunakan masker akan tampil pesan "TIDAK BOLEH KELUAR RUMAH” pada LCD. Pesan tersebut juga dikirim ke Smartphone penghuni rumah melalui aplikasi telegram.

d. Sistem harus mampu mengaktifkan LED Indikator dan buzzer sebagai penanda bahwa penghuni menggunakan masker atau tidak pada saat keluar rumah.

Adapun blok diagram dari sistem yang dirancang dapat dilihat pada Gambar. 1.

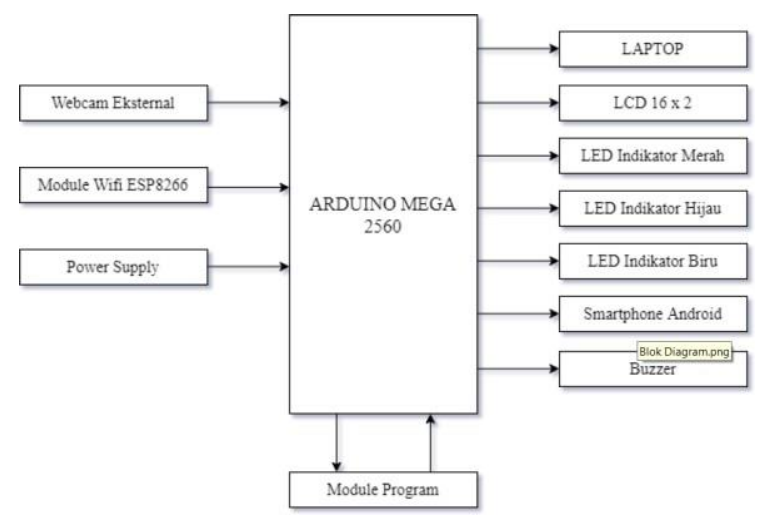

Gambar 1. Blok Diagram Sistem Deteksi Penggunaan Masker

Pada blok diagram gambar 1 tersebut terlihat bahwa sistem yang dirancang menggunakan Arduino Mega2560 sebagai pengendali. Sumber daya dari Arduino berasal dari power supply. Webcam eksternal berfungsi untuk mengambil data gambar (image) dan ESP8266 berfungsi sebagai modul Wifi. Sedangkan outputnya sistem ini berupa LCD 16x2, LED indikator, buzzer, dan Smartphone Android. Tegangan sumber power supply peralatan berasal dari jala-jala

Jurnal KomtekInfo Vol . 8, No. 4 (2021) 232-238 
PLN 220VAC. Keseluruhan sistem dikendalikan oleh Arduino Mega2560 berdasarkan data yang tersimpan dalam memory program modul tersebut. Adapun rancangan fisik alat dapat dilihat pada Gambar. 2.

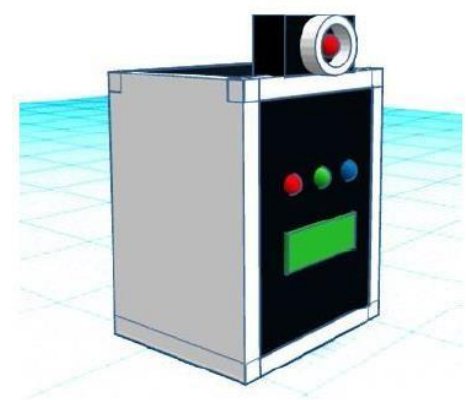

Gambar 2. Rancangan Fisik Alat

Gambar. 2 di atas merupakan rancangan fisik alat dari sistem yang dirancang. Pada bagian atas kotak alat terdapat webcam eksternal, sedangkan pada bagian depan kotak alat terdapat LED indikator dan LCD 16x2. Modul ESP8266 dan buzzer terletak di dalam kotak alat. Buzzer ini akan berbunyi jika penghuni rumah tidak menggunakan masker saat keluar dari rumah.

\subsection{Implementasi Sistem}

Pada tahap ini dilakukan implementasi dari sistem yang telah dirancang. Implementasi sistem dilakukan dengan membangun perangkat (alat) yang telah dirancang sebelumnya baik dari segi perangkat keras (hardware) maupun perangkat lunak (software). Dari segi perangkat keras (hardware), alat pendeteksi penggunaan masker ini dibangun mulai dari pembuatan rangkaian elektronik dan pembuatan kotak alat. Bentuk alat yang sudah selesai dapat dilihat pada Gambar. 3.

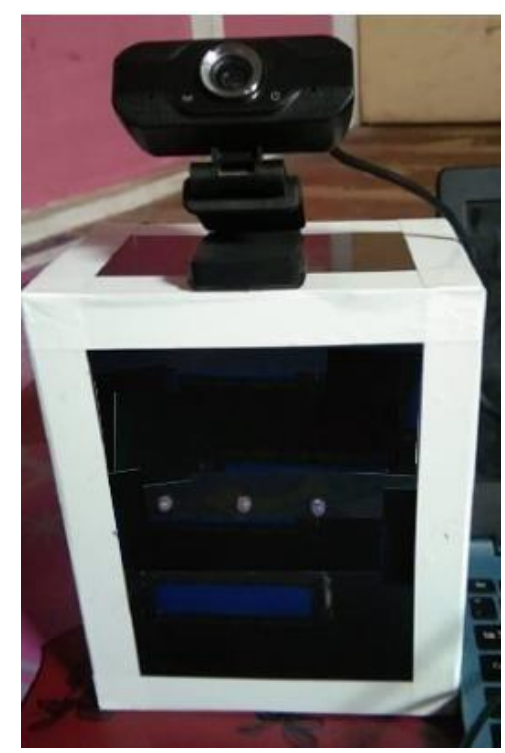

Gambar 3. Bentuk Fisik Alat
Selanjutnya dari segi perangkat lunak (software) dilakukan pembuatan program menggunakan software Arduino IDE. Jika program telah selesai dilanjutkan dengan upload coding program ke modul Arduino Mega2560 seperti tampilan pada Gambar. 4.

Gambar 4. Tampilan Upload Arduino IDE

Jika program sukses di upload ke dalam arduino, maka akan muncul tulisan "Done uploading". Langkah selanjutnya adalah melakukan pengujian terhadap sistem yang telah selesai dirancang.

2.3 Pengujian Sistem

Pada tahap ini dilakukan pengujian terhadap sistem yang telah dirancang. Mekanisme pengujian sistem sebagai berikut :

a. Unit Testing

Pengujian masing-masing unit komponen program untuk meyakinkan bahwa sudah beroperasi secara benar.

b. Module Testing

Pengujian terhadap koleksi unit-unit komponen yang saling berhubungan.

c. Subsystem Testing

Pengujian terhadap koleksi modul-modul yang membentuk suatu subsystem (aplikasi).

d. System Testing

Pengujian terhadap integrasi subsystem, yaitu keterhubungan antar subsystem.

\section{Hasil dan Pembahasan}

Setelah peralatan dibuat, selanjutnya peralatan diuji untuk mengetahui sejauh mana kinerja dari peralatan yang dirancang. Adapun gambar fisik keseluruhan dari alat pendeteksi penggunaan masker tersebut dapat dilihat pada gambar 3 .

\subsection{Pengujian Kamera (Webcam)}

Pengujian dilakukan dengan menjalankan aplikasi teachablemachine yang dapat diakses pada https://teachablemachine.withgoogle.com/. Setelah aplikasi dijalankan, pilih Webcam. Hasil pengujian pada Gambar. 5.

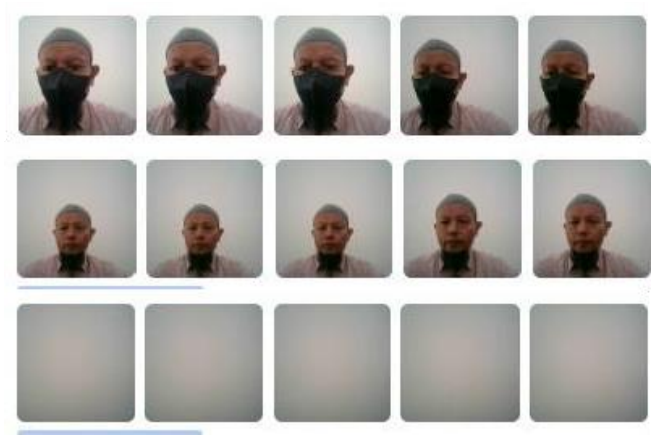

Gambar. 5. Hasil Pengujian Kamera (Webcam)

Berdasarkan hasil pengujian tersebut, kamera (webcam) dapat dikatakan bekerja dengan baik, karena mampu menampilkan gambar (image) 
yang sama dengan kondisi yang nyata (real) di depan kamera tersebut. Pada gambar 5 terlihat bahwa terdapat 5 buah foto orang yang tidak menggunakan masker, 5 buah foto orang yang menggunakan masker dan 5 buah foto tidak ada orang sama sekali.

\subsection{Pengujian LCD 16x2}

Pengujian dilakukan dengan membuat program untuk menampilkan 2 buah pesan pada LCD. Pesan pertama yaitu ; "BOLEH KELUAR RUMAH" dan pesan kedua yaitu "TIDAK BOLEH KELUAR RUMAH". Setelah program dijalankan pada Arduino Mega2560, selanjutnya tampilan pesan pada LCD tersebut dilihat secara kasat mata. Hasil pengujian dapat dilihat pada Tabel. 1.

Tabel. 1. Tabel Pengujian Tampilan LCD

\begin{tabular}{ccc}
\hline $\begin{array}{c}\text { Pengujian } \\
\text { ke- }\end{array}$ & $\begin{array}{c}\text { Pesan teks yang } \\
\text { dikirimkan dari Arduino }\end{array}$ & $\begin{array}{c}\text { Pesan yang tampil } \\
\text { pada LCD }\end{array}$ \\
\hline 1 & "BOLEH KELUAR & BOLEH KELUAR \\
& RUMAH" & RUMAH \\
2 & "TIDAK BOLEH & TIDAK BOLEH \\
& KELUAR RUMAH" & KELUAR RUMAH \\
\hline
\end{tabular}

Berdasarkan hasil pengujian tersebut, LCD dapat dikatakan bekerja dengan baik, karena mampu menampilkan pesan teks sesuai dengan pesan yang dikirimkan dari Arduino Mega 2560.

\subsection{Pengujian LED Indikator}

Pengujian dilakukan dengan membuat program untuk menyalakan dan memadamkan LED indikator dengan memberikan logika pada input LED Indikator tersebut. Hasil pengujian dapat dilihat pada Tabel. 2.

Tabel 2. Tabel Pengujian LED Indikator

\begin{tabular}{ccc}
\hline $\begin{array}{c}\text { Pengujian } \\
\text { ke- }\end{array}$ & $\begin{array}{c}\text { Logika Input Rangkaian } \\
\text { LED Indikator }\end{array}$ & Kondisi LED \\
\hline 1 & '0' & Padam \\
2 & $' 1 '$ & Menyala \\
\hline
\end{tabular}

Berdasarkan hasil pengujian tersebut, LED indikator dapat dikatakan bekerja dengan baik, karena mampu menyala dan padam sesuai dengan instruksi logika yang dikirimkan dari Arduino Mega 2560.

\subsection{Pengujian Rangkaian Buzzer}

Pengujian dilakukan dengan memberikan tegangan pada input rangkaian buzzer berupa tegangan dengan logika ' 0 ' dan logika ' 1 ', kemudian mendengarkan bunyi yang dihasilkan oleh buzzer. Hasil pengujian dapat dilihat pada Tabel. 3.

Tabel. 3. Tabel Pengujian Buzzer

\begin{tabular}{ccc}
\hline $\begin{array}{c}\text { Pengujian } \\
\text { ke- }\end{array}$ & $\begin{array}{c}\text { Logika Input } \\
\text { Rangkaian Buzzer }\end{array}$ & Kondisi Buzzer \\
\hline 1 & '0' & Tidak aktif \\
2 & $' 1$, & Aktif / Mengeluarkan Suara \\
\hline
\end{tabular}

/ bunyi yang bisa didengar dalam radius \pm 10 meter

Dari hasil pengujian dapat dilihat bahwa pada saat logika ' 0 ' diberikan, buzzer tidak aktif (tidak mengeluarkan suara). Sedangkan pada saat logika ' 1 ' diberikan, buzzer aktif mengeluarkan suara/bunyi yang

bisa didengar dalam jarak \pm 10 meter. Berdasarkan hasil pengujian tersebut, rangkaian buzzer dapat dikatakan bekerja dengan baik, karena memenuhi syarat untuk dijadikan sebagai alarm untuk mengingatkan bahwa masker belum digunakan saat keluar rumah.

\subsection{Pengujian Klasifikasi Wajah}

Pada tahap ini dilakukan pengujian wajah yang menggunakan masker dan wajah yang tidak menggunakan masker. Caranya adalah dengan membuat dataset wajah menjadi 3 klasifikasi yaitu ; 1 . Yang menggunakan masker, 2. Yang tidak menggunakan masker dan 3. Dataset saat tidak ada wajah di depan kamera (webcam). Hasil pengujian dapat dilihat pada Gambar. 6.

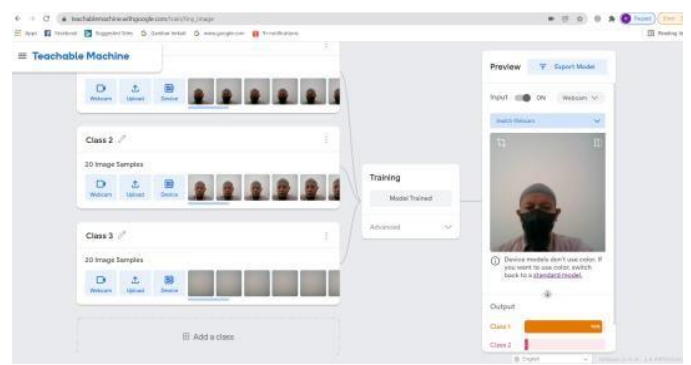

(a)

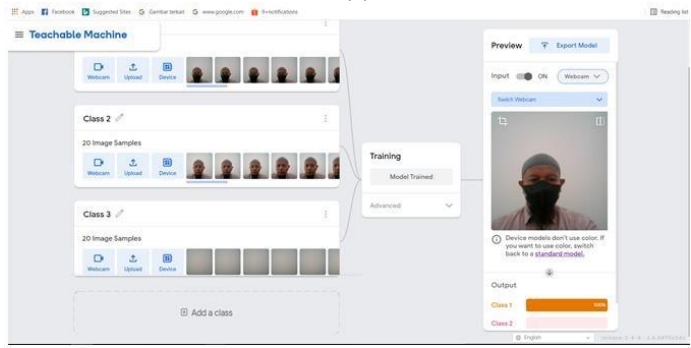

(b)

Gambar 6. Pengujian Wajah Yang Memakai Masker

Pada Gambar. 6 tersebut merupakan pengujian wajah menggunakan masker. Terlihat prediksi Class 1(wajah menggunakan masker) berkisar antara 96\% sampai dengan $100 \%$. Berdasarkan hasil pengujian tersebut dapat dikatakan proses deteksi wajah menggunakan masker bekerja dengan baik dapat dilihat pada Gambar.7. 


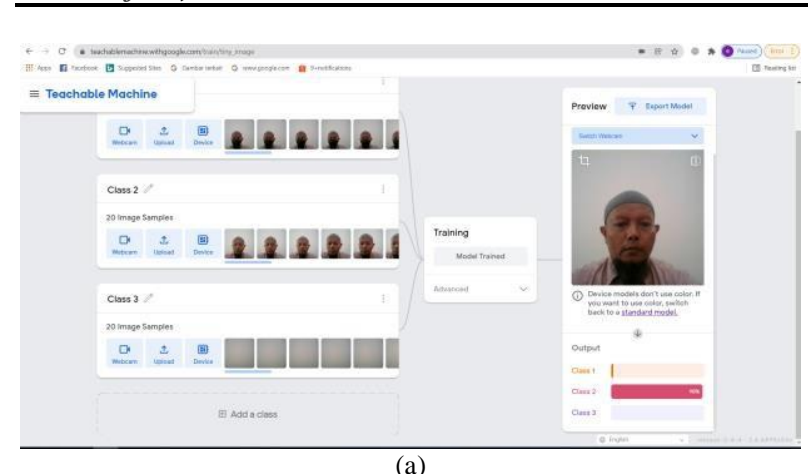

(a)

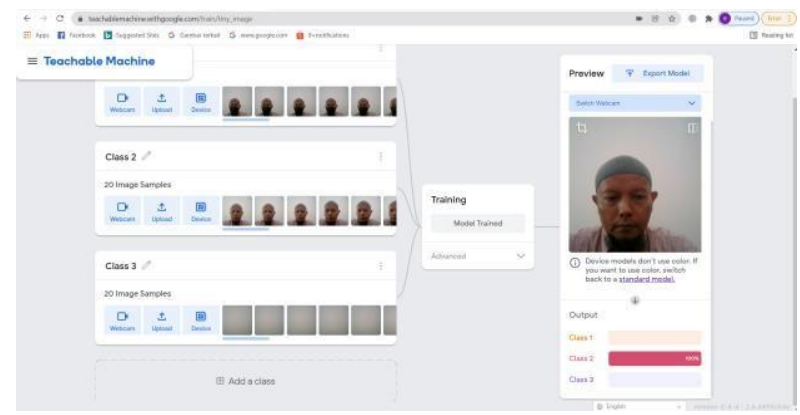

(b)

Gambar 7. Dataset Wajah Yang Tidak Memakai Masker

Pada Gambar. 7 tersebut merupakan pengujian wajah yang tidak menggunakan masker. Terlihat prediksi Class 2 (wajah yang tidak menggunakan masker) berkisar antara 98\% sampai dengan $100 \%$. Berdasarkan hasil pengujian tersebut dapat dikatakan proses deteksi wajah yang tidak menggunakan masker bekerja dengan baik pada Gambar. 8 .

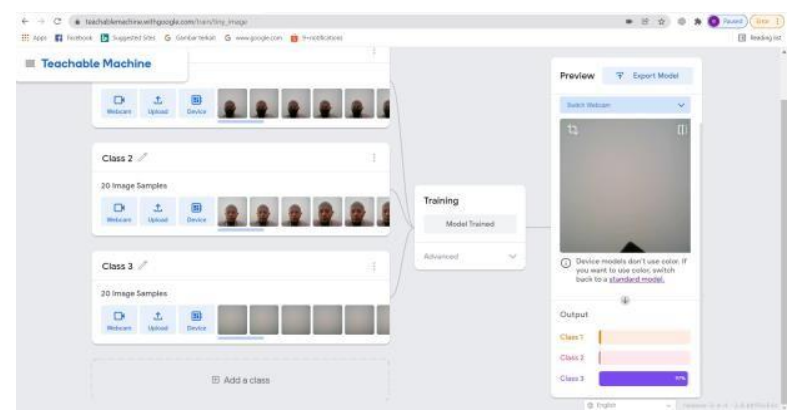

(a)

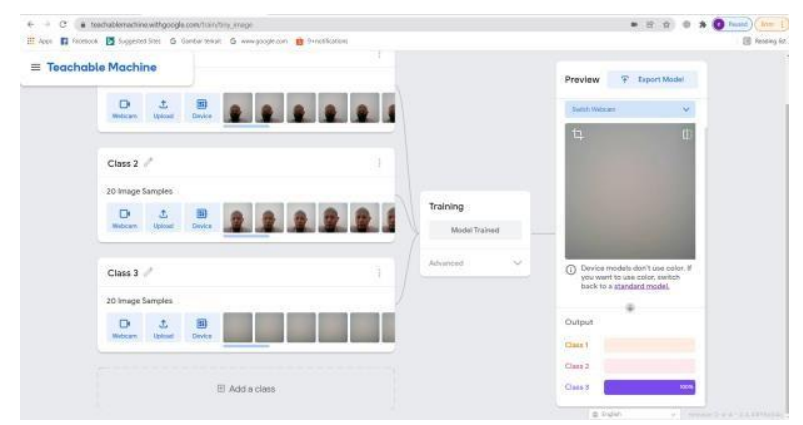

(b)

Gambar. 8. Dataset Wajah Yang Tidak Memakai Masker

Pada Gambar. 8 tersebut merupakan pengujian yang tidak ada wajah sama sekali. Ini berguna untuk memastikan tidak ada orang di hadapan kamera (webcam) tersebut. Terlihat prediksi Class 3 (Tanpa wajah / tidak ada orang) berkisar antara 97\% sampai dengan $100 \%$. Berdasarkan hasil pengujian tersebut dapat dikatakan proses deteksi kondisi tidak ada wajah / orang bekerja dengan baik.

\subsection{Pengujian Pengoperasian Peralatan Secara Keseluruhan}

Pada tahap ini dilakukan pengujian keseluruhan terhadap sistem yang telah dirancang. Mekanisme pengujian sistem sebagai berikut:

a. Hubungkan alat ke sumber tegangan PLN. Jika peralatan tidak ada masalah, maka akan tampil nama pada LCD 16x2 tsb seperti Gambar. 9.

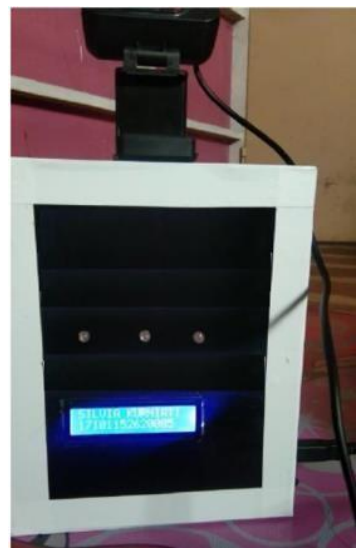

Gambar. 9. Tampilan Awal Sistem Saat Pertama Kali Diaktifkan

b. Koneksikan Android dan Laptop pada wifi yang sudah diaktifkan.

c. Buka website "Teachablemachine.withgoogle. com". Bagi menjadi 3 Kelas yang ada di image project disajikan pada Gambar. 10.

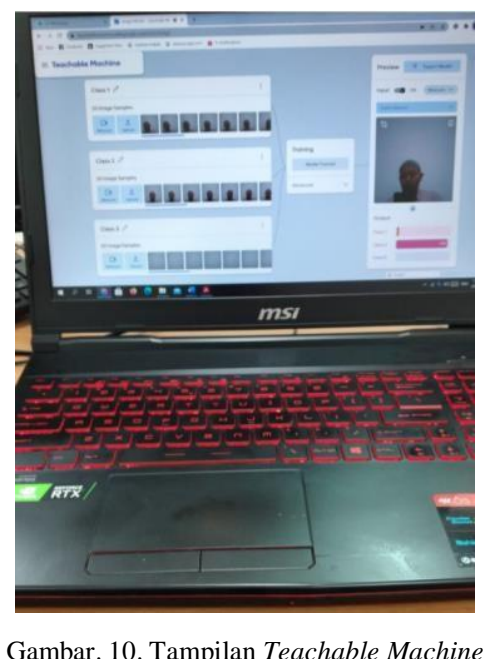

d. Kemudian upload masing-masing data yang sudah dikumpulkan sebelumnya.

e. Setelah itu klik "Train Model" lalu data akan di "training". 
f. Setelah di training, ubah Input dari Off jadi On. Download link di aplikasi Teachable Machine lalu copy kan ke coding P5.

g. Buka coding P5 di browser dan buka aplikasi P5 di Laptop. Didalam aplikasi tersebut akan mendeteksi port arduino, setelah itu sambungkan USB arduino ke Laptop. Lalu P5 akan mendeteksi COM arduino, lalu koneksikan ke COM tersebut. Samakan COM yang terdeteksi dengan coding P5, lalu jalankan coding P5 tersebut.

h. Buka hotspot Smartphone, sambungkan ke ESP8266 dan juga tersambung ke laptop.

i. Berikut tampilan sistem ketika kamera (webcam) mendeteksi tidak ada orang sama sekali disajikan pada Gambar. 11.

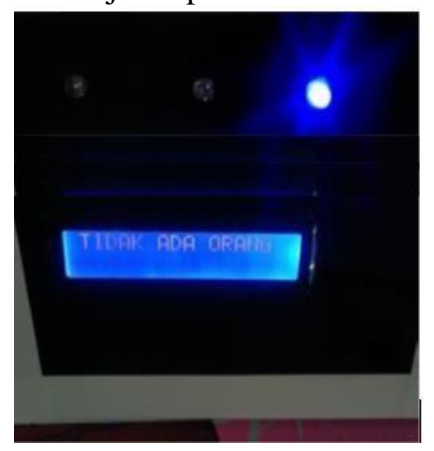

Gambar. 11. Tampilan LCD Saat Tidak Ada Orang Yang Terdeteksi

j. Selanjutnya sistem dicoba mendeteksi orang yang keluar rumah tanpa menggunakan masker. Pesan yang tampil pada LCD dapat dilihat pada Gambar. 12.

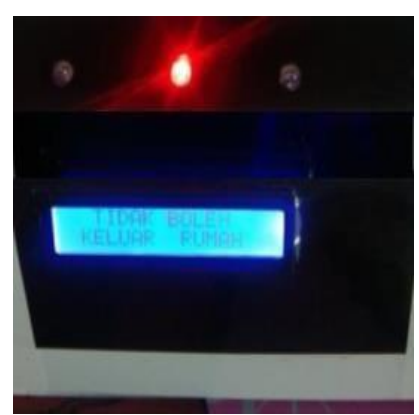

Gambar. 12. Tampilan LCD saat ada orang yang keluar rumah tidak menggunakan masker

k. Kemudian sistem dicoba mendeteksi orang yang keluar rumah tanpa menggunakan masker. Pesan yang tampil pada LCD dapat dilihat pada Gamba.r 13.

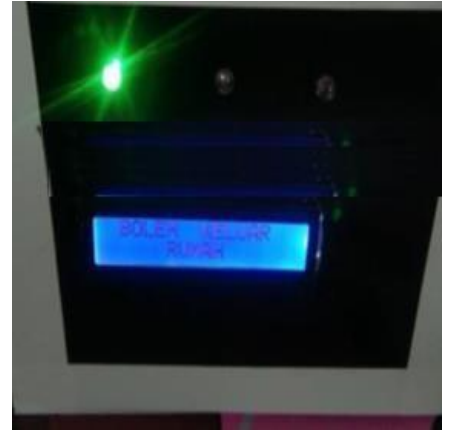

Gambar. 13. Tampilan LCD Saat Ada Orang Yang Keluar Rumah Menggunakan Masker

1. Adapun pesan yang tampil pada aplikasi Telegram di Smartphone dapat dilihat pada gambar 14 berikut ini.

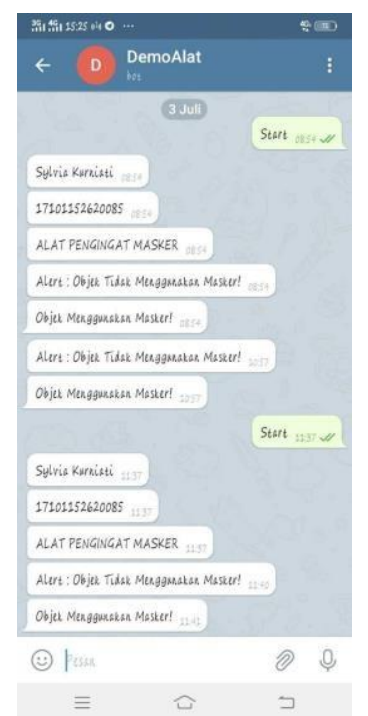

Gambar 14. Tampilan Notifikasi Telegram

Tabel 4 berikut ini merupakan pengujian sistem secara keseluruhan.

Tabel 4. Tabel Pengujian Sistem Secara Keseluruhan

\begin{tabular}{|c|c|c|c|}
\hline $\begin{array}{l}\text { Pengujian } \\
\text { ke- }\end{array}$ & $\begin{array}{c}\text { Kondisi } \\
\text { Pengguna }\end{array}$ & $\begin{array}{c}\text { Pesan yang } \\
\text { tampil pada } \\
\text { LCD }\end{array}$ & Status \\
\hline 1 & $\begin{array}{l}\text { Tidak Ada di } \\
\text { Depan Kamera } \\
\quad(\text { webcam })\end{array}$ & $\begin{array}{l}\text { "Tidak Ada } \\
\text { Orang" }\end{array}$ & Ok \\
\hline 2 & Pakai Masker & $\begin{array}{c}\text { "Boleh Keluar } \\
\text { Rumah" }\end{array}$ & Ok \\
\hline 3 & Pakai Masker & $\begin{array}{l}\text { "Boleh Keluar } \\
\text { Rumah" }\end{array}$ & Ok \\
\hline 4 & Pakai Masker & $\begin{array}{c}\text { "Boleh Keluar } \\
\text { Rumah" }\end{array}$ & Ok \\
\hline 5 & Pakai Masker & $\begin{array}{l}\text { "Boleh Keluar } \\
\text { Rumah" }\end{array}$ & Ok \\
\hline 6 & Pakai Masker & $\begin{array}{l}\text { "Boleh Keluar } \\
\text { Rumah" }\end{array}$ & Ok \\
\hline 7 & Pakai Masker & $\begin{array}{l}\text { "Boleh Keluar } \\
\text { Rumah" }\end{array}$ & Ok \\
\hline 8 & Pakai Masker & $\begin{array}{l}\text { "Boleh Keluar } \\
\text { Rumah" }\end{array}$ & Ok \\
\hline 9 & Tidak Pakai & "Tidak Boleh & Ok \\
\hline
\end{tabular}

Jurnal KomtekInfo Vol . 8, No. 4 (2021) 232-238 


\begin{tabular}{|c|c|c|c|}
\hline & Masker & $\begin{array}{l}\text { Keluar } \\
\text { Rumah” }\end{array}$ & \\
\hline 10 & $\begin{array}{l}\text { Tidak Pakai } \\
\text { Masker }\end{array}$ & $\begin{array}{l}\text { "Tidak Boleh } \\
\text { Keluar } \\
\text { Rumah" }\end{array}$ & Ok \\
\hline 11 & $\begin{array}{l}\text { Tidak Pakai } \\
\text { Masker }\end{array}$ & $\begin{array}{l}\text { "Tidak Boleh } \\
\text { Keluar } \\
\text { Rumah" }\end{array}$ & Ok \\
\hline 12 & $\begin{array}{l}\text { Tidak Pakai } \\
\text { Masker }\end{array}$ & $\begin{array}{l}\text { "Tidak Boleh } \\
\text { Keluar } \\
\text { Rumah" }\end{array}$ & Ok \\
\hline 13 & $\begin{array}{l}\text { Tidak Pakai } \\
\text { Masker }\end{array}$ & $\begin{array}{l}\text { "Tidak Boleh } \\
\text { Keluar } \\
\text { Rumah" }\end{array}$ & Ok \\
\hline 14 & $\begin{array}{l}\text { Tidak Pakai } \\
\text { Masker }\end{array}$ & $\begin{array}{l}\text { "Tidak Boleh } \\
\text { Keluar } \\
\text { Rumah" }\end{array}$ & Ok \\
\hline 15 & $\begin{array}{l}\text { Tidak Pakai } \\
\text { Masker }\end{array}$ & $\begin{array}{l}\text { "Tidak Boleh } \\
\text { Keluar } \\
\text { Rumah" }\end{array}$ & Ok \\
\hline
\end{tabular}

Dari hasil pengujian secara keseluruhan pada tabel 4 terlihat bahwa pengujian semua kondisi pengguna yang dilakukan menghasilkan pesan yang sesuai pada LCD. Ini membuktikan bahwa sistem deteksi penggunaan masker saat keluar rumah dapat bekerja dengan baik. Dengan demikian sistem yang dirancang bisa digunakan dan ditempatkan di setiap rumah, sehingga diharapkan bisa menurunkan angka penyebaran virus Covid-19 ini.

\section{Kesimpulan}

Berdasarkan penelitian yang telah dilakukan dapat ditarik kesimpulan bahwa secara keseluruhan peralatan yang dirancang dan dibuat telah dapat bekerja dengan baik. Hal ini didasarkan pada pengujian terhadap masing-masing bagian dalam blok diagram, pengujian klasifikasi wajah dalam menggunakan masker dan yang tidak menggunakan masker. Disamping itu juga didasarkan pada pengujian sistem secara keseluruhan juga diperoleh hasil yang relatif baik yaitu dengan akurasi berkisar antara 96 sampai dengan 100 persen. Namun sistem yang dirancang masih menggunakan laptop sebagai pendukung dalam pengenalan wajah yang menggunakan masker tersebut. Diharapkan sistem pendeteksi penggunaan masker ini bisa diaplikasikan dengan menggunakan kontroler yang lain yang berbasis AI (Artificial Intelligence) seperti Jetson
Nano, sehingga penggunaan laptop tidak diperlukan lagi.

\section{Daftar Rujukan}

[1] Ellyvon Pranita, "Diumumkan Awal Maret, Ahli: Virus Corona Masuk Indonesia dari Januari," www.Kompas.Com, 2020. [Online]. Available: https://www.kompas.com/sains/read/2020/05/11/130600623/di umumkan-awal-maret-ahli--virus-corona-masuk-indonesia-darijanuari. [Accessed: 27-Apr-2021].

[2] B. Putra Wibowo, S. Olivia, A. Sodikin, and R. Fitrina, "the Analysis of Health Alert Card (Hac) Distribution and BodyTemperature Checking Towards Customer'S Satisfaction At Soekarno-Hatta Airport in Pandemic Covid-19 Era,' Proceedings.Itltrisakti.Ac.Id, pp. 302-312.

[3] A. Nsawotebba et al., "Effectiveness of thermal screening in detection of COVID-19 among truck drivers at Mutukula Land Point of Entry, Uganda," PLoS One, vol. 16, no. 5 May, pp. 1$11,2021$.

[4] U. Achlison, "Analisis Implementasi Pengukuran Suhu Tubuh Manusia dalam Pandemi Covid-19 di Indonesia," J. Ilm. Komput. Graf., vol. 13, no. 2, pp. 102-106, 2020.

[5] E. Suprayitno, S. Rahmawati, A. Ragayasa, and M. Y. Pratama, "Pengetahuan dan Sikap Masyarakat dalam Pencegahan COVID-19," J. Heal. Sci. (Jurnal Ilmu Kesehatan), vol. 5, no. 2, pp. 68-73, 2020.

[6] S. Asnawati, J. Manurung, L. Rosa, and V. Sinaga, "Penyuluhan Dan Sosialisasi Masker Di Desa Sifahandro Kecamatan Sawo Sebagai Bentuk Kepedulian Terhadap Masyarakat Ditengah Mewabahnya Virus Covid 19," J. Abdimas Mutiara, vol. 1, no. September, pp. 115-123, 2020.

[7] S. Ardiputra, M. R. Prawira, M. Tasbir, S. U. Permata, N. Listiawati, and L. Qadrini, "Pemerintah Dalam Rangka Mendukung Pencegahan Penyebaran Covid-19 Pada Masyarakat Desa Pallis," Community Dev. J., vol. 1, no. 3, pp. 395-400, 2020.

[8] D. Kuswoyo, "Pencegahan Penularan Covid-19 dengan Pemberlakuan Perilaku 3M," J. Peduli Masy., vol. 3, no. 2, pp. 123-128, 2021.

[9] Arduino, "ARDUINO MEGA 2560 REV3," 2019.

[10] E. Naf'an, "Rancang Bangun Alat Penampung Buku Berbasis Arduino Pada Sistem Pengembalian Buku Layanan Mandiri," J. Sistim Inf. dan Teknol., vol. 3, pp. 76-81, 2021.

[11] J. Oxer and H. Blemings, Practical Arduino. 2010.

[12] AI-Thinker Team, "ESP-12E WiFi Module Version 1.0," Shenzhen Anxinke Technol. CO LTD, pp. 1-18, 2015.

[13] A. Latifah, "Webcam Application for Classrooms Monitoring," IOP Conf. Ser. Mater. Sci. Eng., vol. 434, no. 1, 2018.

[14] S. Watkiss, Learn Electronics with Raspberry Pi. .

[15] N. Cameron, Arduino Applied: Comprehensive Projects for Everyday Electronics. 2019.

[16] E. Team, "Lesson 09 Buzzer," 2019. [Online]. Available: https://www.elecfreaks.com/learnen/microbitKit/Starter_Kit/starter_kit_case_09.html.

[17] K. Zhu, "An Educational Approach to Machine Learning with Mobile Applications," pp. 1-82, 2019 